\title{
The Mirage of Procedural Justice and the Primacy of Interactional Justice in Organizations
}

\author{
Rasim Serdar Kurdoglu ${ }^{1}$ (1)
}

Received: 15 March 2018 / Accepted: 25 April 2019 / Published online: 30 April 2019

(c) Springer Nature B.V. 2019

\begin{abstract}
This paper offers a novel situational approach to study organizational justice in which the proposed unit of analysis is managerial behavior manifested in argumentation rather than employee justice perceptions. The currently dominant theoretical framework in justice research, which is built on justice perceptions, neglects the unique features of organizational order and vulnerability of procedural justice perceptions. As the procedural justice concept belongs chiefly to a spontaneous market order under which the rule of law is made possible, it is inappropriate to transfer this concept to an organization in which the rule of authority is dominant. Therefore, except the limited legal domain in which managerial freedom is restrained by laws, procedural justice in organizations represents a mirage that can give rise to hypocritical managerial actions that can legitimate morally controversial outcomes via eristic tactics. In contrast, interactional justice is of great importance to organizations in that employees and organizations can ensure their rational economic exchanges without deception. However, current formulations of interactional justice often regard interactions as a palliative recipe designed to alleviate reactions to outcomes and not as a constituent of distributive justice. Perelman's argumentation theory can offer a new conceptualization of interactional justice that addresses this gap.
\end{abstract}

Keywords Argumentation theory $\cdot$ Organizational justice $\cdot$ Procedural justice $\cdot$ Interactional justice $\cdot$ Legitimacy $\cdot$ Hayek

Hayek (1973, 1976, 1979), who appears to have received no attention from organizational justice researchers, conceptualize organizations in a unique way, which can have striking implications for organizational justice research. Hayek (1973) divided social orders into mainly two categories, spontaneously evolved market orders and deliberately designed orders of organizations. Hayek (1973, 1976) argued that spontaneously evolved market orders and organizations have different natures that bring about the following distinct justice implications: (1) While a spontaneously evolved market order involves individuals who act by their self-interests without any deliberate social coordination, an organization involves individuals who are subject to the directions of an authority who established the goals. (2) While the rules of just conduct in a spontaneous market order are composed of abstract negative procedural norms that only impose what people ought not to do, administrative

Rasim Serdar Kurdoglu

r.s.kurdoglu@bilkent.edu.tr

1 Faculty of Business Administration, Bilkent University, Ankara, Turkey rules in an organization are composed of concrete positive instructions to command what its members ought to do. (3) While impersonal market mechanisms are responsible for distribution of rewards in a spontaneously evolved market order, organizational administration is responsible for the distribution of rewards in organizations. (4) While a spontaneously evolved market order is amenable to procedural justice expectations that can be protected by the evolving rule of law and independent judiciary, an organization is a deliberate design that cannot evade the rule of authority for its internal administration. Hayek $(1976,1979)$ also argued that individuals can easily confound the distinct nature of these two orders and hold conflicting expectations inimical to the functioning of the order in which they operate. For instance, individuals can wrongfully expect market outcomes in an organization and complain about injustice; or they can unreasonably expect organizational arrangements in a free-market and complain about social injustice.

Based on the distinction between organizations and market orders, this present study argues that the oft-studied procedural justice standards (Leventhal 1976, 1980; Thibaut and Walker 1975, 1978) borrowed from Anglo-American 
legal systems are a mirage for organizations as they are only applicable to spontaneously formed market orders. Thus, except the limited legal domain where a managerial agency is restricted by certain legal obligations, it is not feasible for managerial decisions to be subject to procedural justice expectations in organizations. In an organized order, an authority dictates the outcomes, rather than agentless procedures of market order.

A different situation exists for interactional justice as it should be considered as a part of distributive justice in organizations. There are two reasons for that situation: (1) Integrity of interactions directly influences distributive outcomes in organizations. Organizational politics research (Cullen et al. 2018; den Nieuwenboer et al. 2017; Ferris et al. 2007; Higgins et al. 2003; Kapoutsis et al. 2012; Vigoda 2000) attests to the fact that distribution of rewards in organizations are susceptible to social influence and communication tactics. (2) Integrity of interactions can also influence market behavior of employees and organizations. Although an organization is an order of authority, employees and organizations are in free-market exchange relationships that necessitate having interactions conducted without deception for both parties to have rational choices in employment markets. This is so as "the prices determined by just conduct of the parties in the market, i.e., the competitive prices arrived at without fraud, monopoly and violence, was all that justice required" (Hayek 1976, p. 73). Accordingly, this paper will take deception as primary violation of interactional justice, and it will particularly pay attention to cases where managers can hypocritically use organizational rules through eristic (winning oriented) modes of interaction to legitimate their controversial decisions.

This paper takes organizational rules and procedures merely as promises and orders of an organization since; (1) they do not determine the organizational outcomes without agency; (2) they are usually not spontaneously formed but instead deliberate products of managerial agency; and (3) they are open to different interpretations and enforcements susceptible to eristic argumentation (strategically arguing to defeat a disputant by sophistry). Yet, this paper does not refute the value of procedures in setting employee expectations and justice judgements (Colquitt and Zipay 2015; Kickul 2001).

By drawing on Hayek's $(1960,1973,1976,1979)$ justice and rule of law theories, this paper mainly explains why procedural justice as it is currently studied is a mirage, and how interactional justice, within a new understanding based on Perelman's $(1963,1979,1980,1982)$ argumentation theory, should have primacy in organizations. In this regard, it introduces the important role of managerial legitimation attempts as a response to unfairness concerns. The paper accordingly elaborates on how managerial legitimations are prone to eristic communication tactics when currently formulated procedural and interactional justice approaches are exploited to manage issues of organizational fairness hypocritically.

As will be presented next, this paper essentially offers a situational approach to study organizational justice in which interactional justice is treated as a constituent of distributive justice in organizations. Conceiving interactional justice as a constituent of distributive justice has significant implications as it might let researchers be more conclusive about empirically demonstrating the existence of organizational injustice, and it can perhaps help transcend the relativistic discussions on moral philosophy, which is another constituent of distributive justice.

\section{Situational Approach to Study Organizational Justice}

This paper does not aim to repudiate the currently dominant theoretical framework of organizational justice which descriptively focuses on justice perceptions. Rather, this paper aims to supplement that framework with a different perspective, which is sensitive to the nature of economic exchanges and organizational realities, and which deals with managerial behavior instead of employee perceptions. Justice researchers justifiably attend to procedural justice perceptions, as employees may use procedural justice as a heuristic device to form their distributive justice expectations and eventually estimate their trust in authorities (Colquitt and Zipay 2015; Lind 2001). Thus, this paper does not imply false consciousness on the part of employees, nor does intend to inspire emancipative research projects since procedural justice perceptions might have appropriate functions for employees. However, while the current paradigm has its own merits, it involves an unbalanced focus on employee justice perceptions without a regard for unique features of organizational order that defies procedural justice. This paper remedies that problem by offering a new theoretical approach, i.e. the situational view, supported by the norms of free-market ideals and rational decision-making. In this novel approach, procedural justice is considered as a mirage in organizations but organizational procedures are still recognized as an important element of interactional justice.

The proposed situational view overall focuses on how managerial behavior and argumentation can impact distributive justice in organizations. In that sense, it shifts the unit of analysis in organizational justice research from justice perceptions to managerial behavior and reasoning. It remedies the problems of current theoretical framework as it induces justice researchers to study managerial behavior and reasoning, in addition to employee perceptions that can be admittedly categorized as distributive, procedural and interactional. The offered framework is also useful to study how 
employees' justice perceptions that are not aligned with the organized order can be abused by managers.

From this paper's situational approach, distributive justice in organizations is comprised of two parts; (1) moral approach of managers, and (2) interactional justice of managers. The proposed situational view is presented in Fig. 1. Elements of moral approach of managers, which are briefly mentioned in Fig. 1, can be derived from the ethical decision-making literature (Bazerman and Sezer 2016; KishGephart et al. 2010; Schwartz 2016; Weber and Wasieleski 2001; Zollo et al. 2017), which is out of the scope of this paper. The paper will instead expand on what interactional justice involves and how it can be violated by eristic arguments of managers as briefly captured in Fig. 1. Eristic communication and hypocrisy concepts will be introduced first.

\section{Eristic Talks and Hypocrisy}

Eristic talks are characterized by an abusive use of rhetoric performed primarily to defeat another party rather than searching for truth (Perelman and Olbrechts-Tyteca 1969). In eristic talks, interlocutors can uncompromisingly cling to their opinions in a one-sided and deceitful manner to obstinately impose their opinions (Walton 1999). Eristic dialogs can involve dishonorable and devious uses of rhetorical techniques in communication to make weak arguments appear strong in the eyes of a spectator who can determine the winner (Booth 2004; Margolis 1995; Perelman and OlbrechtsTyteca 1969). In these respects, eristic arguments can be exploited to legitimate contentious managerial decisions in a hypocritical manner.

Hypocrisy can involve failing to practice what one preaches (Stone and Fernandez 2008); holding double standards, i.e., applying moral values only to others while alleviating oneself from professed values (Polman and Ruttan 2012); or exhibiting an urge to appear moral while avoiding the consequences of being moral (Batson et al. 1997). The idea of hypocrisy in all respects implies resorting to the use of impression management tactics to create an image of ostensible compliance with explicitly endorsed ethical standards while breaching the same standards. In this sense, it reflects a sort of dishonesty in concealing moral contradictions. Conversely, hypocrisy performs some favorable functions as a lubricant of social and political life, as it brings civility to these realms (Davidson 2004). Complete moral integrity is argued to be destructive to social relations in this regard since hypocrisy brings about politeness and alleviates social frictions. Likewise, Brunsson $(2002,2007)$ argued that hypocrisy and the resulting inconsistencies between words and deeds are almost a necessity for responding to conflicting expectations of legitimacy held by different stakeholders. However, the benign functions of hypocrisy are unlikely to eradicate its deceptive destructiveness,
Fig. 1 Situational view of organizational justice

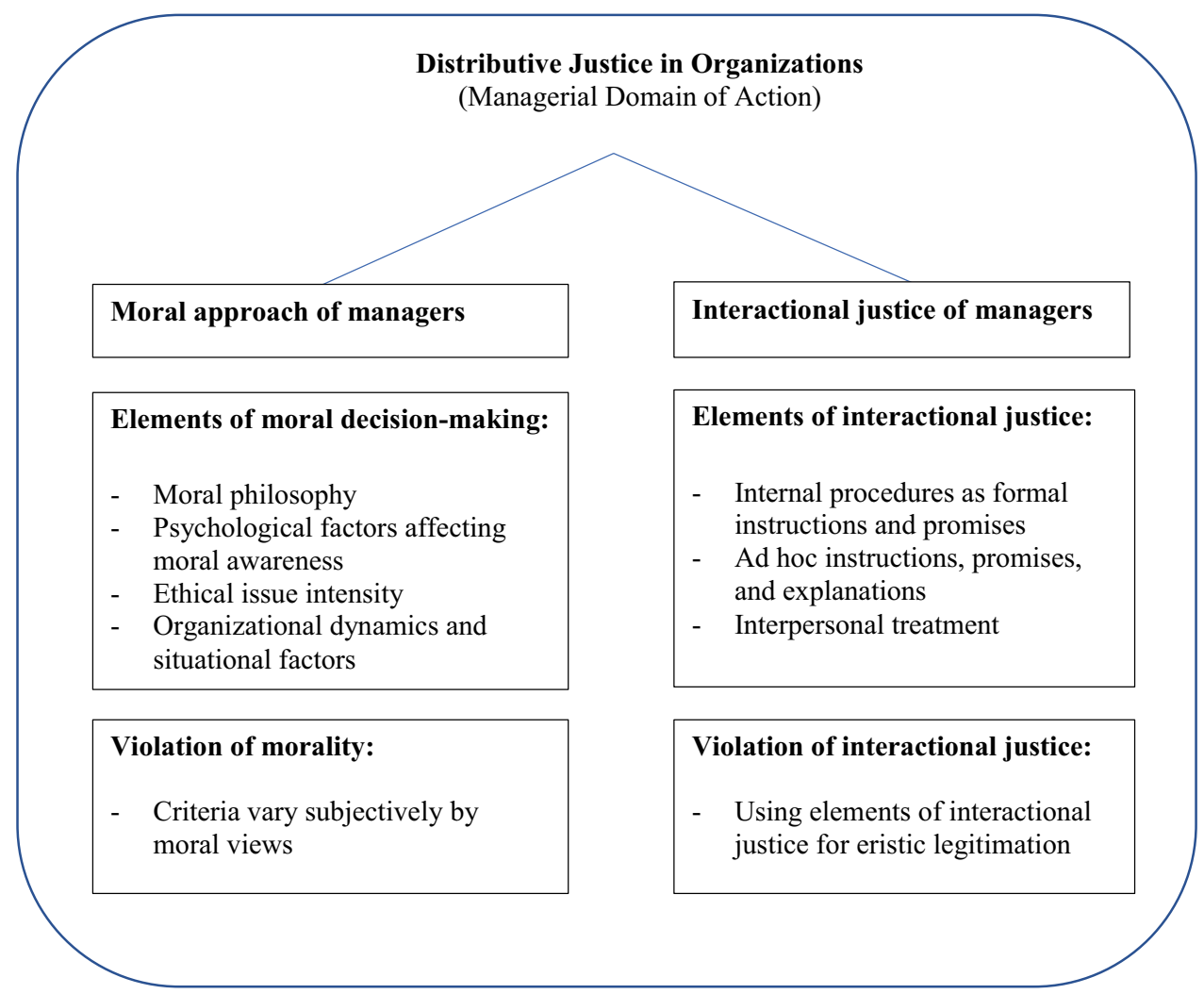


especially when employees are concerned about the fairness of managerial decisions. Current conceptualizations of the organizational literature fail to respond to such managerial expediencies, as will be explained in the following section.

\section{Merits and Shortcomings of the Justice Literature}

This paper will use fairness and justice synonymously to follow the general practice used in the literature. While legal understanding of these terms may differ (Goldman and Cropanzano 2015), both concepts in organizational practice commonly refer to a claim of worthiness. That is, when an individual perceives something as unfair or unjust, he or she is basically claiming that he or she does not deserve the treatment inflicted. In a similar fashion, the organizational justice and fairness literature has concentrated on perceptions of fairness and justice framed as individuals' moral reactions to how they are treated (Rupp et al. 2017).

Research on subjective fairness or perceptions of justice has a long and established presence in the organizational behavior literature (Colquitt et al. 2001; Fortin et al. 2016; Rupp et al. 2017). As of 2018, the Web of Science database has identified over 4000 studies conducted on the topic of organizational justice. It is a remarkably sophisticated field, as it is able to illuminate (1) why employees care about organizational justice, (2) how employees assess justice and how they respond, (3) the outcomes of their perceptions of injustice, (4) and precursors of their judgements of justice (Colquitt and Zipay 2015; Crawshaw et al. 2013). However, the current conceptualization of organizational justice research (Fortin and Fellenz 2008; Rupp et al. 2017) may impede the further contributions of justice scholars, especially in terms of having a positive impact on organizational practices, due to its usual theoretical foundations, which will be challenged in this paper with a new theoretical view for investigating organizational justice.

It has been accepted that employees pay attention to justice because they have self-interested instrumental and relational concerns along with principled moral preferences or so-called deontic urges for justice (Cropanzano et al. 2003, 2017). Employees can also use their perceptions of justice as a proxy measure to assess whether they should trust their superiors (Colquitt and Zipay 2015; Lind 2001). Likewise, positive justice assessments can increase employees' willingness to cooperate (Melkonian et al. 2011; Van Dijke et al. 2015). On the other hand, research highlights that perceptions of justice and their consequences can change with experience and time (Fortin et al. 2016). However, the relationship between perceptions of justice and employee motivation and performance has been firmly established (Colquitt et al. 2013; Fortin 2008).
Conlon et al. (2005) grouped the impacts of perceived unfairness on organizational outcomes into three categories: a possible decline in task performance and employee compliance; withdrawal behaviors among organizational members; and finally, counterproductive work behaviors. Workplace stress has also been documented to be closely related to organizational fairness in terms of perceptions of unfairness serving as both a source of stress and as a mediator in determining how individuals cope with stressful workplace conditions (Vermunt and Steensma 2001). The organizational justice literature is overall replete with documentation of the detrimental effects of perceptions of unfairness on performance outcomes (Colquitt et al. 2013). Therefore, perceptions of fairness cannot be ignored or considered lightly by managers as employees unavoidably desire fairness for their own welfare.

\section{Trilogy of Organizational Justice Perceptions}

Research on organizational justice has largely been based on a well-known trilogy to categories perceptions of justice. Accordingly, the form studied most widely is distributive or so-called outcome justice, which is referred to as the fairness of returns granted to employees relative to their contributions (Adams 1963). The second form is procedural justice, which is referred to as perceptions of the fairness of procedures leading to decision-making (Cohen-Charash and Spector 2001; Leventhal 1980; Thibaut and Walker 1978). Finally, the third form is interactional justice, which involves how fairly an employee is treated in terms of the manner of personal behaviors experienced (interpersonal fairness) and the quality of information exchange (informational fairness) involved in interactions with their superiors (Colquitt 2001; Bies 2005). Interactional justice is often treated as a constituent of procedural justice but has distinct features. Interactional perceptions of justice capture employees' reactions to their personal contact with their supervisors or managers, whereas procedural perceptions of justice capture employees' reactions to organizational policies and procedures as enacted by upper management teams. In this way, interactional justice have been measured and classified separately in a statistically meaningful manner albeit with some correlations (Bies 2005; R. Cropanzano et al. 2002).

When procedural justice studies were first theorized for legal disputes by Thibaut and Walker $(1975,1978)$, the focus was on how disputants respond when procedures allow for them to voice their concerns with control over the resolution process (Rupp et al. 2017). Later, Leventhal (1980) identified six criteria that can be specifically used by individuals in assessing the fairness of procedures. As summarized elegantly by Cohen-Charash and Spector (2001, p. 280), Leventhal's criteria include the following: "(a) the consistency rule, stating that allocation procedures should be consistent 
across persons and over time; (b) the bias-suppression rule, stating that personal self-interests of decision-makers should be prevented from operating during the allocation process; (c) the accuracy rule, referring to the goodness of the information used in the allocation process; (d) the correctability rule, dealing with the existence of opportunities to change an unfair decision; (e) the representativeness rule, stating that the needs, values, and outlooks of all the parties affected by the allocation process should be represented in the process; and (f) the ethicality rule, according to which the allocation process must be compatible with fundamental moral and ethical values of the perceiver". These two frameworks were then carried to organizational contexts, as employees are expected to appreciate opportunities to voice their views and to observe these democratic principles in the execution of procedures (Folger and Greenberg 1985). Additional procedural criteria such as evidence-based performance appraisals and the job-relatedness of employee selections have also been studied as contextualized rules rather than overarching theoretical principles (Bobocel and Gosse 2015; Rupp et al. 2017).

Of the two categories of interactional justice, studying informational justice chiefly concerns how explanations, in the form of justifications or excuses, can alleviate concerns of unfairness (Bies 2005; Colquitt et al. 2001). Justifications are conceived as explanations used to legitimate decisions whereas excuses are conceived as explanations used to deny "full responsibility by citing some external cause or mitigating circumstance" (Shaw et al. 2003, p. 445). In this regard, employees' perceptions have been studied in terms of whether they find provided explanations to be reasonable, thorough, timely and truthful (Colquitt 2001; Rupp et al. 2017; Shapiro et al. 1994). By contrast, interpersonal justice, the second form of interaction justice, focuses on the civility of the treatment received (Bies and Moag 1986). According to this perspective, important concerns include the politeness and respectfulness of the treatment (Colquitt 2001).

\section{The Managerial Perspective in Justice Research}

For each category of the trilogy, the justice literature offers guidelines for managers on ways to avoid unwanted consequences of unfairness reactions (Cropanzano et al. 2007; Cuguero-Escofet et al. 2014; Colquitt and Zipay 2015). One of the most striking lessons of justice research for managers is then to signal their fairness successfully and to avoid offending their subordinates. In this regard, research helps managers carefully enact their procedures (Bobocel and Gosse 2015; Colquitt et al. 2001; Crawshaw et al. 2012; Maccoun 2005) and guides them in their interactions with employees (Ambrose et al. 2002; Bies 2005; Cohen-Charash and Spector 2001; Colquitt 2001). Accordingly, research has largely focused on ways to manage subordinates who experience a sense of unfairness (Rupp et al. 2017), as this feeling is justifiably conceived as a problem for employee performance. For this reason, the majority of fairness research has heavily focused on how perceptions of fairness can be controlled or how unwanted consequences can be alleviated (Colquitt et al. 2013; Cugueró-Escofet and Fortin 2014). Thus, the issue has generally been studied from managers' isolated view on the perceptions of fairness held by their subordinates.

This disproportionate empirical and conceptual emphasis on aggrieved employees' perceptions may lead researchers to neglect the corresponding actions of peers and managers who are accountable for perceptions of unfairness. In this regard, justice in organizations carries the risk of being studied not as a management problem but as managers' problem in engaging with their employees. Perceptions of justice are indubitably important as a managerial problem, as such perceptions have real consequences for employee performance. However, an isolated focus on employee perceptions without regard for the nature of managerial reactions to such perceptions can be a deficient approach to research on fairness in organizations. Moreover, such an approach may cause researchers to turn a blind eye to deceptive managerial attempts that insincerely target employees' senses of unfairness (Fortin and Fellenz 2008). This one-sided approach may neglect the use of cynical impression management tactics in managing complaints of unfairness rather than promoting conscientious managerial actions aimed to sincerely pursue fairer workplaces (Cugueró-Escofet and Fortin 2014).

In a similar way, some researchers (Cuguero-Escofet et al. 2014; Fortin and Fellenz 2008; Jerald Greenberg 1988, 2009; Lefkowitz 2009) in this field have begun to question the dominance of one-sided views on research. Fortin and Fellenz (2008) particularly problematized the status quo by arguing that managers are becoming increasingly more adept at exploiting cynical tools to encourage perceptions of fairness rather than sincerely aiming to encourage fairness improvements. Fortin and Fellenz defined such impression management tactics as hypocritical approaches to fairness. In this respect, Fortin and Fellenz reflected on the possibility that organizational researchers may be unwittingly promoting deceptive tactics to practitioners and thereby contributing to the deterioration of fairness in organizations. Greenberg $(1988,2009)$ similarly argued that managers' primary motives in addressing justice issues are often related to brand-building activities that use ostensible behaviors and hypocritical statements to strengthen their influence over their employees. As Greenberg (2009) noted, managers are not usually known for their fairness; instead, widespread negligence regarding fairness issues has been frequently characteristic of managerial practices.

A few arbitrarily chosen papers published in reputable journals can illustrate the concerns raised in this paper: (1) 
Loi et al. (2012) documented that employees are increasingly worried for procedural justice when there is a high job insecurity. They indicated that these worries are attenuated when managers are personally perceived as ethical, especially in cases where employees have a low power distance orientation. (2) Sung et al. (2017) demonstrated that employees' commitment can be decreased after an incentive pay scheme if there is a low procedural justice climate. (3) Matta et al. (2017) indicated that employees tend to have less stress and emotional exhaustion when they are consistently treated unfairly than when they are occasionally treated fairly. (4) He et al. (2014) studied how procedural justice influence employee engagement, and whether individuals' moral identity mediates this relationship. (5) Xu et al. (2017) similarly investigated how the relationship between employee justice perceptions and ethical leadership behavior can be mediated by employees' trust levels.

In all these cited studies, a possible social engineering agenda of managerial agency seems to be pursued by research aims and outcomes, at least as an implied aspiration. Hence, procedural justice perceptions seem to be explored for the sake of managerial policy-making, rather than for the sake of an organizational governance design that can foresee managerial abuse of power by eristic legitimation arguments. Yet, this paper does not intend to accuse justice researchers of being on the side of management. It is quite likely that any researcher studying justice would be pleased to help employees concerned with injustice. However, the current theoretical constructions implicitly, and probably unwittingly, lead to research that primarily deals with the concerns of managers and neglect employee concerns as well as board of directors' and top executives' concerns over managerial actions.

\section{Conceptual Vulnerability of Justice Research and its Negative Consequences}

If there are some negative side effects of justice research, they are likely to stem from the division of justice perceptions into three descriptive forms without a regard for the nature of exchange relationships. Organizational scholars have remarkably demonstrated that when procedures are ostensibly applied fairly (procedural justice) and when employees are informed kindly and thoroughly, while their views are taken into consideration (interactional justice), then they tend submit to managerial decisions such that negative outcomes of allegedly unfair decisions can be avoided (Bobocel and Gosse 2015; Cohen-Charash and Spector 2001; Collins and Mossholder 2017; Colquitt et al. 2013; Dailey and Kirk 1992). It is precisely such critical connections that can give rise to hypocritical managerial applications. Particularly procedural perceptions of justice can be used hypocritically as a means of legitimating normally unjustifiable distributive outcomes. Interestingly, some studies (Skitka and Houston 2001; Skitka 2002; Skitka and Mullen 2002) indicate that procedural perceptions of justice can be ineffective at eliminating resentments over unfairness among employees when the distribution outcomes strongly violate the prevailing moral principles of individuals. The findings of such studies can indicate that employees can become suspicious of hypocrisies realized through ostensible procedural justice.

The fairness of procedures and outcomes and the nature of surrounding interactions are indeed interdependent (Colquitt et al. 2013). However, researchers tend to treat each form of fairness in an analytically detached manner and to focus on one form of fairness in their studies (Törnblom and Kazemi 2015). Moreover, due to the moral intricacies embedded in distributive justice, researchers often focus on procedural and interactional justice (Lefkowitz 2009). This categorization of perceptions has been brought about the notion that perceptions of justice can be controlled separately. However, in practice, it is difficult to imagine a just procedure or just interaction without a just outcome. When procedural perceptions of justice can be antecedent of distributive perceptions of justice (Leventhal 1980), any inconsistencies between them may denote the presence of hypocrisy. In this sense, divide-and-control strategies may at times work to create a hypocritical semblance of justice in the workplace.

Procedural justice, from its current scope of covered definitions and carried from Anglo-American private law traditions to the realm of organizations, is attractive to employees because it offers the lure of the rule of law. The rule of men and women over other men and women is inherently prone to issues of fairness, as rulers can be culpable of unfairness. By contrast, the rule of law turns administrations of justice into an impersonal procedural mechanism that can alleviate concerns regarding distributive justice by suppressing the role of agency. However, the rule of law cannot be a valid proposition for organizations, as it has only currency for a spontaneous social order marked by principles of freemarket mechanisms functioning within certain traditions and institutions (Hayek 1973, 1979).

Organization refers to a social order of a deliberate design marked by personal authority that inevitably involves the engagement of agency, which is crucially susceptible to influence of organizational politics (Gotsis and Kortezi 2010; Rosen et al. 2017; Vigoda 2000), unlike a distributive mechanism of market order. In this regard, a genuine satisfaction of procedural criteria, as defined by Thibaut and Walker $(1975,1978)$ and Leventhal $(1980)$, is not only a mirage for an organized order but also ontologically goes against the nature of organizations ruled through authority and managerial discretion embroiled with organizational politics. Therefore, aiming for positive procedural 
perceptions of justice in organizations may facilitate the impression management strategies in organizations, as procedural justice is theoretically incompatible with an organized order. However, this is not an empirical assertion that administrators of organizations are necessarily Machiavellian in their use of procedures as the aim is here merely to raise the theoretical possibilities.

As organizations are steered by personal authority over free individuals who offer their labor as an economic exchange based on available information, the compatible form is interactional justice, which should be treated as a constituent of distributive justice rather than as a separate form to alleviate distributive justice reactions or as a subsidiary of procedural justice. Interactional justice is a constituent of distributive justice as it can directly influence distributive outcomes in organizations as well as it can distort market behavior of employees and employers within employment markets. Before elucidating how the concept of interactional justice should be expanded according to that perspective, the following section will outline Hayek's rule of law and justice theories in greater detail to demonstrate the infeasibility of the use of procedural justice in organizations based on its current definition.

\section{A Mirage of Procedural Justice in Organizations}

Hayekian liberal social view has four pillars, namely, spontaneous order, the rule of law, individual liberty and limited government, that complement one another (Macedo 1999). Hayek's $(1973,1976,1979)$ theory relies on an appreciation of abstract procedural norms spontaneously formed through social and cultural evolution within a free-market system that can outperform any rationally designed order such as organization.

\section{Rule of Law and Procedural Justice of Market Order}

Hayek's $(1973,1979)$ concept of the rule of law differs from the rule of legislation, as the latter normally represents the will and design of governments albeit with power of democratic representation. For organized orders such as governments, the rule of legislation is an administrative necessity for their internal conduct but not for regulating the private conduct of citizens (Hayek 1979). A rule of law is by contrast a broader and largely stable moral framework that can even limit the will of power holders as constitutions aim to do (Hayek 1973), drawing its power from spontaneously formed traditions, institutions and the prevailing opinions of people. The rule of law thus cannot be a product of any legislator, as it emerges through socio-cultural evolution as language does (Daumann 2007; Hayek 1973). However, the government can lay down rules of just conduct by uncovering the law but not by inventing such rules (Hayek 1979). Governments must nevertheless enforce the rule of law while also providing some basic provisions that cannot be supplied by market mechanisms, including securing a minimum income for impoverished citizens when a country is wealthy enough to afford this responsibility (Hayek 1973). In conducting these operations, governments can legislate positive instructions for its workforce to decree what should be followed for targeted ends. By contrast, governments cannot issue such instructions to other citizens (Hayek 1976).

For Hayek (1973), social order is spontaneously coordinated through market prices, conventions and language, reflecting socially shared values, whereby governments should respect related dynamics and ensure the rule of law. Hayek (1976) believed that one should not interrupt this agentless and evolving harmony with government intervention because no one can produce any intended outcomes; the market has its own dynamics that cannot be effectively reined in, and interventions may even have disastrous consequences. For him, ingenious market algorithms produce better outcomes than any human design (Bowles et al. 2017). Furthermore, Hayek advocated for evolutionary agnosticism by claiming that we cannot predict how markets will evolve and that therefore any deliberate institutional design is doomed to fail to produce any intended results (Vanberg 2014). Therefore, he highlighted the importance of sustaining individual liberties and the rule of law to allow social evolution to run its own course, as he argued that it is destined to take its best form when unrestrained. According to Hayek (1979), laws exist to ensure the health of this spontaneous order but not to restrict individual freedom for other reasons. In this respect, rules of just conduct cannot be used to arrange economic distribution; therefore, rules are solely a part of procedural justice (Lister 2013).

Hayek (1976) believed that one should succumb to the sovereignty of markets because this agentless order protected by procedural justice is the best system we have, although it breaks the link between merits and rewards. As a result, Hayek (1976) argued that social distributive justice is an absurd concept, a dangerous superstition, and a form of semantic fraud in a market economy, as individuals do not govern markets, and there is no one to blame. Individuals can be just or unjust, but an agentless market and social order cannot be either. He also argued that merits, skills and efforts do not warrant success because serendipity can at times inevitably surpass everything.

\section{Hayek's Views and Human Resources Management Practices}

If Hayek's views are applied to contemporary HR (human resources) management practices and to justice research, 
there are striking consequences. In organizations, there are those who can be held accountable for others' perceptions of unfairness. Therefore, Hayek considers the possibility of outcome injustice manifesting in organizations, as visible agents can be identified as potential perpetrators. When social justice in the form of distributive and outcome justice can be viewed as a mirage in free-market economies with certain institutional structures, procedural justice becomes a mirage in organizations as agents dominate organizational decisions rather than a spontaneous order protected by spontaneously formed rules of just conduct. The procedures of organizations are not a product of an evolving spontaneous order, as they represent the will and rational designs of executives (except for legally enforced rules, as organizations also form part of the larger social order). Moreover, unlike the laws defined by Hayek's $(1960,1973)$ theory, organizational procedures are not prohibitive negative norms, as they can apply positive instructive norms. In addition, in contrast to a democratic societal order, there is no separation of power in organizations. Sometimes the same individuals or units of an organization can be both legislators as well as executors and judges of their procedural systems. This situation only changes when employees sue their organizations for misconduct, which denotes the occurrence of legal disputes rather than that presence of an ordinary organizational issue. As governmental employment regulations typically tend to impose limits via basic obligatory requirements and protective measures (Blanpain et al. 2007), the domain of managerial discretion and the role of organizational procedures remain very large in organizations.

In Hayekian terms, procedures applied in organizations are legislations that are rationally invented instructions of an authoritative body that is itself restricted by rule of law. By contrast, rules of just conduct of the law are culturally evolved moral rules that are based on negative norms to mark the domain of free action that should even govern the actions of the government. Hence, one cannot invent Hayekian law-like moral rules for organizations, as such rules are a product of the evolution of broader society. Instead, individuals can carry such socially evolved moral rules into their organizations to form their justice expectations. For instance, employees can invoke justifications borrowed from different institutions of social life, such as markets, family, or religion, to formulate their arguments for justice (Boltanski and Thevenot 2006; Friedland and Alford 1991).

\section{The Uses and Frailties of Organizational Procedures}

Despite their imperfections, procedural rules are not useless in organizations as they can empower aggrieved employees in their pursuit of justice (Kersley et al. 2006), as much as they can empower managers in their attempts to legitimate their controversial decisions. Indeed, any institutional arrangement, including procedures, would constrain and enable the actions of all actors (Harmon et al. 2015; Hoefer and Green 2016). In this regard, organizational procedures are simply elements of an ethical climate that guides employees on acceptable behavior (Wang and Hsieh 2013). Yet, with the exception of legally enforced procedures, procedures are simply written instructions given by upper management teams and written promises that are open to different interpretations and forms of execution. Therefore, they represent just one of the elements of organizational interactions.

The flexibility of organizational procedures is not necessarily conducive to unfairness since applying rules in a pharisaic manner, i.e., adhering to the literal meanings of rules, can also result in the denial of justice (Perelman 1963, 1980). Yet, formalities in bureaucracies and rules designed based on technical rationality are inherently not capable of answering moral questions on their own (Breslin and Wood 2016; Brubaker 2006; Camic et al. 2005; Hodson et al. 2013; Jackall 2010; M. Weber 1991). For instance, the effectiveness of grievance procedures is often contentious (Mccabe and Rabil 2002; Walker and Hamilton 2011; Currie et al. 2017). Policies and procedures may likewise make a promise of fairness in critical human resources decisions (Brown et al. 2010), but they can also be used hypocritically to develop morally problematic dominance under the guise of the rule of law, which cannot exist in an organizational order.

On the other hand, culturally formed informal procedures of organizations (Blader and Tyler 2003) are no different than formal procedures for the scope of this paper. Implementation and interpretation of informal procedures are similarly susceptible to managerial abuses since there is no independent third party (like judiciary) to enforce those rules in an unbiased way. More crucially, the existence of informal rules does not change the fact that agentless distributive mechanism of markets does not exist in organizations.

In sum, within the organizational domain, agency is undeniable despite procedures. The key concern in this study is that managers can misuse their authority as well as organizational procedures to legitimize their decisions hypocritically. "The effective limitation of power is the most important problem of social order" (Hayek 1979, p. 128). With that concern, eristic elements of managerial legitimacy arguments are emphasized in this study as a potential indicator of the abuse of managerial power. Before dealing with that abuse of power as a matter of interactional justice, the following section will first elucidate the concept of legitimation. 


\section{Concerns for the Legitimacy of an Action}

Legitimacy and fairness (or justice) are different concepts, although they are closely correlated. "Legitimacy is a generalized perception or assumption that actions of an entity are desirable, proper, or appropriate within some socially constructed system of norms, values, beliefs and definitions" (Suchman 1995, p. 574). Perceptions of fairness draw on a sense of deserved treatment while perceptions of legitimacy are based on the social acceptability of certain treatment. At the level of individual perception, there is a distinct overlap between legitimacy and procedural perceptions of fairness (Johnson et al. 2006; Tyler 2006; Tost 2011). However, as Tost (2011) notes, fairness represents just one dimension of personal legitimacy judgment. Tost shows that besides moral dimensions, such as fairness, individuals have instrumental and relational concerns when they form judgements of legitimacy.

\section{Justice, Legitimacy and Power Differences}

Justice (or fairness) and legitimacy respond to different needs of parties participating in a power relationship. Justice is normally a demand from the weaker party, whereas legitimacy is a necessity for the powerful party. The weak need justice to prevent mistreatment from the powerful, while the powerful need legitimacy to avoid resistance and sanctioning against using power. A claim of injustice is inherently a cry for help and compassion from others who can address the powerful. By contrast, a claim of legitimacy signals the acceptability of the deployment of power and it notifies others that any internal resistance or outside intervention is not justifiable. Likewise, managers demand perceptions of positive legitimacy as a form of relational exchange from their subordinates when they believe that their subordinates' expectations of procedural justice are satisfied (Tyler and Lind 1992).

The powerful, according to the definition of power, do not require mercy from others to enact their will, as this would signal a position of powerlessness. However, the powerful should be still concerned with being legitimate. First, even the weakest party can resist and inflict costly harms while not being able to defeat the powerful. Second, the powerful may not remain as powerful after losing legitimacy. The survival of the powerful can be threatened when institutional support is eroded once legitimacy is lost (Meyer and Rowan 1977). Thus, legitimacy should be the main concern of the powerful, while fairness and justice should be the main concern of the weak for survival. In a typical hierarchical organization, managers have such power over their subordinates. It is through such a frame that managers as the powerful party are likely to be more interested in enhancing their legitimacy rather than focusing on fairness or justice.

In terms of social psychology, the importance of legitimacy lies in the observation that individuals are generally willing to submit to legitimated rules, directions, practices and decisions without external enforcement (Tyler 2006; 2011). Social psychologists likewise highlight the important role of social ideologies in setting legitimacy expectations (Sidanius et al. 2004; Sidanius and Pratto 2011). In this regard, socially shared views of legitimacy, that is, some culturally preordained criteria for what should be perceived as legitimate and what should not, have important functions in preventing the emergence of personal frictions and in coordinating people's behaviors in any social order, including organizations. That perspective acknowledges legitimation as a more effective and civilized tool of the powerful, in contrast to close monitoring or coercion, for the purposes of securing consent to domination.

Although legitimacy perceptions can be conceived individually such as perceptions of fairness, legitimation extend beyond individual perception, as it plays a performative social role in the sense that it involves determining what should be accepted as socially appropriate in practice. In this regard, legitimation can override assessments of personal legitimacy, as legitimation is a process that can activate institutional support for a legitimated action or decision (Bitektine and Haack 2015; Suddaby et al. 2017). Legitimation involves a rhetorical process that has been extensively studied by neo-institutional scholars (Green and Li 2011; Harmon et al. 2015; Hoefer and Green 2016; Suddaby and Greenwood 2005).

\section{Legitimacy and Institutions}

Institutions can be defined as social orders that apply largely constant cultural rules, practices, and structures that can influence the behaviors of individuals and organizations operating under their domain (Scott 2001). According to neo-institutional theory, when individuals and organizations gain legitimacy by institutional standards, they can increase their chances of surviving by attracting more resources from their external environments (Erkama and Vaara 2010). Hence, being legitimate involves acting in compliance with institutional expectations, which is rewarded by increased external support for the survival of the entity that acts legitimately.

In moving toward the institutional logics approach, it is possible to explain more complex variations of an institutional order. The logics approach departs from neo-institutional theory by shifting the focus from structurally imposed conformity pressures to institutional variations and the role of agency in constructing what is legitimate. According to this 
view, individuals and organizations are conceived as operating within a society in which different institutions are intertwined (Thornton and Ocasio 1999). Each institution is characterized by a specific way of thinking that is based on a distinct set of assumptions and values, which are referred to as institutional logics (Thornton et al. 2012). For instance, Friedland and Alford (1991) reported on peculiar logics of markets, government bureaucracy, family, religion and democracy. The logics ingrained in these institutions are conceived to constrain individuals' thoughts, communications and perceptions. However, as any social setting can host a set of conflicting institutional logics (Seo and Creed 2002), individuals and organizations are enabled through these contradictions between each institutional logics to shape their social settings accordingly (Thornton et al. 2012; Thornton and Ocasio 2013). In this sense, multiple institutional logics can be invoked to claim legitimacy through distinct combinations (Cloutier and Langley 2013; Green et al. 2008; Harmon et al. 2015; Hoefer and Green 2016). Such conflicting logics can also be exploited by organizational actors in various ways to pursue political interests and to assert authority over others (Boxenbaum and Battilana 2005; Misangyi and Weaver 2008). Such political behaviors render rhetoric an important element of an institutional order, as political actions can be rhetorically legitimated by playing strategically with institutional logics (Berry 2017; Green 2004; Harmon et al. 2015; Hoefer and Green 2016; Suddaby and Greenwood 2005).

Legitimation can be conceived as a rhetorical assertion of what should be defined as acceptable by evoking socially imposed criteria embedded in institutional logics. Arguments of legitimation can work to eradicate or suppress a personal dispute on fairness from institutional support that comes with being legitimate. However, the legitimation of an action does not have to lead to an institutionalization of legitimated behavior. By contrast, the concepts of institutional work (Lawrence et al. 2011, 2013; Reay et al. 2006) and institutional entrepreneurship (Battilana 2006; Battilana et al. 2009; Garud et al. 2007; Higgins et al. 2018; Micelotta et al. 2017) equate legitimation with the processes of institutional change. However, legitimation may simply have an impact at the micro-level as a daily economic exchange between individuals rather than having a sociological impact. This is also true when individuals want to resolve their disputes on fairness and negotiate the legitimacy of actions. Through such a transaction, argumentation can play a key interactional role, requiring a distinct theory of interactional justice, which will be discussed next.

\section{Perelman's Argumentation Theory and Interactional Justice}

Since current formulations of procedural justice (Leventhal 1980; Thibaut and Walker 1975) are only applicable to an extended order governed by the rule of law, as defined by Hayek $(1973,1979)$, a more appropriate theoretical framework for an organized order will be offered in this section. It will be turned to Perelman's $(1963,1980)$ legal argumentation theory, which emphasizes the role of rhetoric in a legal system in which rules are set via rational design.

In a societal order governed by the rule of law, rules are negative norms merely comprised of abstract principles for unknown ends (Hayek 1973). As these rules of just conduct are a product of cultural evolution, individuals are expected to internalize these rules culturally through a process akin to learning a language without explicitly knowing its grammatical structure (Hayek 1979). Therefore, the interpretation and execution of such rules in particular circumstances are much less likely to arouse disagreements than rationally designed positive rules. By contrast, rationally designed positive rules taking the form of instructions, which are deliberately drawn from abstract principles of justice to be applied for particular ends, can spur heated arguments on how to interpret and apply such rules in particular situations.

To demonstrate the complexities of rationally designed rules, Perelman formulated and tested a rational and universal rule of justice in its most abstract form: "like beings must be treated alike" (Perelman 1963, p. 70). His formal abstract rule of justice dictates identical treatment for essentially identical beings. However, at a concrete level, disagreement on what should be treated as essentially similar and what should be counted as identical treatment is inevitable. For example, it is possible to categorize individuals differently based on their merits, needs, work, societal rank, origins or any combination of these. The question then lies in which criterion should be used to compare individuals and how such a criterion should be applied. We can take certain aspects of a being as 'essential' to our assessment while excluding other aspects as irrelevant. We can also count two different treatments as identical depending on our scaling of a given treatment and our subjective points of view. Thus, Perelman concluded that which criteria should be prioritized cannot be determined rationally or deductively from a rule, as our reference points are value bounded. Nevertheless, Perelman (1980) argued that it would be a slippery slope to have a nominalist conviction to claim that justice is devoid of meaning as if power could reign with no place for reason.

Perelman demonstrated that a reasoning process is applied when decisions on justice are made, which is 
explained in great length in Perelman and OlbrechtsTyteca (1969). This rhetorical process involves achieving the approval an intended audience through argumentation. This process is a necessity when formal and mathematical reasoning does not generate compelling conclusions, as formal reasoning can only occur possible when rules are clearly unambiguous and open to perfectly rational deduction. For instance, self-evident apodictic claims and experimental demonstrations do not require argumentation. By contrast, argumentation can only generate rationally imperfect but reasonable conclusions through practical reasoning. Arguments can be strong or weak but cannot be logically perfect. In this respect, the pursuit of justice requires the use of practical reasoning and the exchange of argumentation to adjudicate conflicting interpretations with reasonable justifications.

\section{Argumentation Theory}

Perelman and Olbrechts-Tyteca (1969) described their theory of argumentation to elucidate how practical reasoning can operate to resolve conflicts. They define argumentation as a rhetorical process characterized by the imperfect and nonconclusive use of rationality to elicit an audience's adherence to an argument made. Perelman and Olbrechts-Tyteca (1969) identified two categories of argumentative schemes: association and disassociation schemes. By association or dissociation, argumentation aims to achieve an agreement through imperfect reasoning that can provide justifications for the advocated theses.

Of the two argumentative schemes, association involves building connections between premises and conclusions. Association can be executed in three ways. The first association scheme involves developing quasi-logical arguments that only partly follow the logical sequence of a syllogism. As an important facet of justice disputes, quasi-logical arguments can be used to defend decisions that are ostensibly against the rules. For instance, via quasi-logical links, ostensible rule incompatibilities can be resolved by alluding to shared presumptions on the spirit of rules (fiction), by creating excuses (falsehood), or by keeping silent so that requirements for justification are denied. The second association scheme involves using arguments that are based on observations, such as by claiming empirical causation or correlation. The third mode of association involves composing arguments that establish a reality through inductive reasoning. This can be executed using two techniques. The first technique involves establishing a structure of reality by providing examples, illustrations, and models. The second technique involves establishing a structure of reality based on analogies.

In contrast with association arguments, dissociation arguments function by severing the conceptual link between an observation and a concept, which indirectly associates observation with another concept. Dissociations function at the conceptual level to deny the categorization of an observation rather than denying an observation. Dissociation thus affords an observation with a new meaning that differs from what is alleged. In this sense, while complaining employees can draw on traditionally or institutionally accepted meanings to make sense of what should be accepted as fair or unfair, managers can establish new criteria for placing an event under another category. Thus, managers can in turn neither reject an observation nor refute institutionally established rules, but they can still maintain consistency in their rejection of unfairness.

Initial premises of arguments can be based on real factors, namely, facts, truths, and presumptions. Fact is based on objectively verifiable sense data, whereas truth involves a verifiable connection between facts, such as theories and laws of nature (Foss et al. 2014). Presumptions are established expectations of how an incidence is expected to proceed under normal conditions (Perelman 1982). Facts, truths and presumptions are assumed initially as real only tentatively. In this respect, such reality assertions are open to tests of empirical verification and argumentation.

Initial premises of arguments can alternatively be on value preferences that are peculiarly agreed upon by the targeted audience. There are three types of preferences: values, value hierarchies and loci of preferable. Of these three, loci of preferable are typical ways of reasoning to justify values and value hierarchies. In this regard, loci of preferable are similar to institutional logics that dictate certain values and hierarchies among the preferred values.

As imperfect reasoning of argumentation alone can be at times insufficient in arbitrating disputes on value judgements, the authority of a person and of or an authoritative cultural prescription can be indispensable (Perelman 1963, 1980). The plurality of individual moral norms in a market economy is not conducive to the development of harmonious moral relationships in organizations based on uniform rules (Wagner-Tsukamoto 2005, 2008). Thus, the problem is not rooted in the power of authority per se, as it is indeed useful to end moral controversies. Instead, the problem relates to the potentially improper use of authority. In this respect, it is crucial to determine whether a matter is judged competently and reasoned thoroughly to end controversy authoritatively (corresponding to 'res judicata' as a legal maxim in Latin) or whether it is hypocritically enforced with misleading appearances of justice talks (Perelman 1963, 1980). As a result, one must determine whether a simple failure of developing communion between interlocutors has occurred or whether dialogs were pretentious.

A failure to achieve agreement on values can result from two factors. First, there can be profound disagreements in the endorsed values of two interlocutors. In such cases, the 
use of authority to adjudicate such disagreement is necessary (Kurdoglu 2019). Second, interlocutors can be simply ineffective at presenting their cases. For Perelman and Olbrechts-Tyteca (1969), an effective speaker should know where he or she should draw attention, which they refer to as the 'presence' of an argument. Presence is related to how an argument is communicated, such as which terms are used and how a basic message is framed to attract attention from a particular audience (Perelman and Olbrechts-Tyteca 1969). As communication is conducted through the use of symbols rather than signs, the selection of symbols changes the perceptions of an audience (Foss et al. 2014). Speakers should thus carefully consider how their framing and overall style may be improved to facilitate communion with an audience. However, when dialog is pretense, maligned possibilities should be considered, and the good will of the audience should be questioned.

\section{Eristic Arguments}

"Analogically, all communication demands good will from the listening interpreter" (Perelman 1980, p. 156). A dialog can be performed to control a situation, while it may hypocritically appear to be executed for resolution (Brunsson 2002). In this regard, Perelman and Olbrechts-Tyteca (1969) distinguish between heuristic dialogs (problem-solving discussions) and eristic dialogs (polemic debates). Heuristic dialogs are conducted on rational grounds with an attentive audience seeking a reasonable resolution, whereas eristic dialogs are conducted to win an argument without any respect for the reasonableness of counterarguments. Eristic arguments operate to force acceptance rather than persuasion and involve sophistry through the use of false dichotomies, plays on words with definitions and distorted logic (Perelman 1963; Poulakos 1995; Walton 1999). Controversial managerial decisions can in the same way be legitimated by a misleading appearance of procedural justice, which can work to control perceptions of unfairness via eristic moves rather than resolving them. For instance, organizations can give voice to their employees in promoting procedural justice via the use of open door policies (Mccabe and Rabil 2002), but in practice, this may be a pretension. In this regard, it is futile to seek agreement as an outcome of eristic dialog (Tindale 2015; Walton 1992).

On the other hand, positioning dialogs as heuristic rather than eristic is a matter of degree rather than a pure distinction. All conversations can have both characteristics to a degree, as completely heuristic and eristic dialogs are two unrealistic extremes of practical argumentation (Percival 2012; Perelman and Olbrechts-Tyteca 1969). Thus, it is not impossible to persuade an audience who tends to pursue an eristic attitude to an extent. However, eristic versus heuristic is a useful categorization for understanding interlocutors' predominant motivations and aspirations in engaging in dialog.

In eristic dialogs, interlocutors can be dogmatic, selfassertive or fanatical in their views (Walton 1999). This can be true for both managers and for their complaining subordinates. However, as managers are typically authorized to have decision-making power, they can protect themselves from their subordinates' eristic talks by declining the requests of their subordinates. For instance, managers can have the authority to decide on whether a demand for fairness is related to unreasonable greed or whether gross victimhood is involved. In other words, managers can wield power over legitimation. Of course, when the accused manager is later judged by another authority through a grievance investigation, then the power of legitimation will shift to the judging authority. By contrast, an employee concerned with unfairness is from the start dependent on the good will of the manager or of any other third decision-making authority involved as a third party to resolve concerns of unfairness.

Studies on interactional justice have successfully informed us that employees can feel offended not just when they face disgruntling outcomes but also when they face incivility or poor communication (Bies 2005; Collins and Mossholder 2017). However, such studies often focus on which explanations or approaches assuage perceptions of unfairness when procedures are enacted (e.g., Shaw et al. 2003; Bobocel and Zdaniuk 2005) rather than exploring the broader performative role of such explanations in levels of justice in organizations. For instance, such studies do not usually consider the fact that explanations can be used hypocritically to achieve legitimacy. They do not sufficiently consider how false or misleading information prevails in organizations despite when such information is not unconvincing for the concerned employees. Moreover, concepts of interactional justice are not removed from procedural justice when kindly delivered, detailed or candid explanations are conceived as auxiliary to the execution of procedures and not as a constituent of distributive justice. By contrast, Perelman's $(1963,1980)$ justice approach is more comprehensive in the sense that it positions communication as a constituent of distributive justice rather than as a palliative cure.

Conceptions of procedural justice given Thibaut and Walker $(1975,1978)$ and Leventhal (Leventhal 1980) contrast with Perelman's $(1963,1980)$ understanding of justice. Thibaut and Walker emphasized the importance of disputant voice as an input. However, the reasoning process of the received input has the upper hand for Perelman rather than the voice itself. Another contrasting point relates to the fact that Leventhal's procedural justice model largely depends on the presence of consistency and accuracy in decision-making. By contrast, Parelman posited that accuracy is not a feasible goal due to scant opportunities for deductive reasoning, and likewise, consistency can be sacrificed when there are 
convincing justifications. Furthermore, Perelman's theory replaces Leventhal's ethicality principle (allocations should appeal to perceivers' ethical norms) with a principle stating that outcomes are dependent on the justified decisions of authorities. Accordingly, when a managerial authority is trying to win an argument in an eristic manner by hypocritically forming justifications merely to appear institutionally acceptable, this results in a breach of interactional justice, as it reflects dishonesty in information exchange. The role of an implied but invisible audience should be identified in this sort of interaction.

\section{Institutional Gaze}

To discuss eristic dialogs and the possibility of winning an argument, a judge must determine the winner as is the case for legal settings (Perelman 1982; Perelman and OlbrechtsTyteca 1969). In an unfairness dialog between a manager and a subordinate, the accused manager is also the judging authority. However, both the manager and the subordinate employee are compelled to put forward institutionally acceptable reasons for their claims because they assume the presence of an institutional gaze. When no institutional gaze as a presumed judge witnessing their actions is present, managers may simply assume unquestioned authority over their decisions and reject addressing any challenges to their decisions. The civility of managers can also be linked to managerial concerns for employee motivation. However, this concern itself can also be attributable to the institutional expectations of managers.

The institutional gaze is an implied audience that can be defined as imagined individuals who may hold the speaker responsible for his or her arguments. Any audience is a construct in the mind of a speaker (Perelman and OlbrechtsTyteca 1969). Thus, interlocutors enter a dialog with certain presumptions for all the audiences they face. Similarly, the institutional gaze is an imagined construct but not for an actual audience. It is a product of the speakers' views of potentially influential members of the institutional order, be it an imagined judge in an employment tribunal or a potential peer or superior who may condemn the speaker. The speakers' view of the institutional gaze is likely to be restrained by preferable values of the institutional order, which are influenced by the prevailing institutional logics.

The imagined capacities of institutional gaze may nonetheless affect the quality of arguments required to win a dispute. "It is indeed the audience which has the major role in determining the quality of argument and the behavior of orators" (Perelman and Olbrechts-Tyteca 1969, p. 35). Thus, it is no surprise that in some cases, even simple excuses and very weak justifications can work to legitimate an allegedly controversial decision when the institutional gaze is imagined to be very crude. In this respect, when speakers tend to attribute excessively low levels of quality to the institutional gaze, this can degrade the quality of arguments required to assume a win. For example, in corrupt cultures, institutional barriers that come with the presence of an imagined institutional gaze may be so low that they may completely lose their regulatory social function. Worse still, the institutional order may be captivated by corrupting logics (Misangyi and Weaver 2008), potentially disabling the function of the institutional gaze.

Despite its potentially unreliable precision, the existence of an institutional gaze is likely to be the force responsible for placing institutional pressure on both parties of a dispute. Employees in this sense can pressure their managers through the presence of an institutional gaze. Otherwise, the power of unfairness arguments is highly diminished or even rendered baseless. Through such a process, persuading the implied audience can be an important goal when the aim is to avoid attention from real authorities who may eventually intervene. Thus, managers can be urged to avoid the risk of being held accountable for their decisions by producing institutionally endorsed legitimations and not just any argument (Kurdoglu 2019). The problem focused in this paper relates to the fact that managers can secure support for their practices and decisions by merely appearing legitimate to an institutional gaze rather than engaging in heuristic discussions with concerned subordinates. This is exactly what distorted procedural fairness applications can achieve via their deceptive appearance. They can problematically incapacitate individuals who pursue justice. Furthermore, when the dialog of unfairness complaints is tainted by eristic and hypocritical attitudes, acting on personal perceptions of unfairness can be not only futile but also destructive for employees concerned in terms of leading to antagonistic relationships.

\section{Conclusion}

Hayek's liberal justice theory aptly presents series of tradeoffs between different ordering mechanisms. However, his conclusion that free-market processes should be the sole determinant of justice is eventually a normative claim based on free-market ideals. Different values and ends can be advocated as opposed to what his classical liberalism endorses. As Arrow (2012) famously demonstrated, every ordering mechanism involves trade-offs in terms of satisfying certain social preferences over others. Moreover, in terms of economic efficiency, a market order is not always the best solution due to market failures (Barney and Hesterly 2006; Zehnder et al. 2017). Such political discussions on desired ends and technicalities of their means are not the subjects of interests in this paper. It is, however, worth to remind that classical liberalism of Hayek is not oblivious to ends 
other than economic efficiency. For instance, Hayek (1960, 1976, 1979) openly advocated safety net for impoverished individuals along with identifying the need for communal support and charity within small groups.

In anyway, one does not have to agree with political conclusions and moral ideals of Hayek to appreciate his classification of justice mechanisms in different orders. From Hayek's (1973) point of view, organizations and markets operate differently as distribution of rewards in organizations depends on managerial authority, whereas 'invisible hand' of markets permits an agentless procedural mechanism for distributive outcomes. This condition prohibits the feasibility of procedural justice in organizations. Nonetheless, both managerial authority and subordinates are engaged in an economic exchange relationship protected by laws and other institutions within the great societal order. Therefore, it is important to note that procedural justice is infeasible only within the free sphere of a managerial authority's actions. Within this free domain, employers usually enjoy a legally defined freedom of action to determine who to promote, recruit, assign or reward more generously than others.

For the managerial domain of freedom, Perelman's (1963, 1980) justice theory offers a suitable framework for studying justice in organizations. Perelman's perspective emphasizes the value of reasoned justice judgements by heuristic (problem solving) discussions between well-intentioned interlocutors operating under institutional criteria of justice. This paper uses Perelman's perspective within a situational economic view, which is not addressed by the descriptive view on justice perceptions. Within the offered theoretical framework, eristic managerial attitudes denote a major violation of interactional justice, as they prevent the proper resolution of concerns over distributive justice. Justice in organizations eventually necessitates the occurrence of problem-solving discussions and the generation of authoritative conclusions rather than eristic sophistry and fait accompli (Perelman 1963) that are nonetheless susceptible to being legitimized by drawing on procedures and soothing interactions. Deception made possible via eristic arguments can impair employees' rational decision-making capacities in organization as well as in the employment market, and may deprive them from the capacity to call for external help from the institutional environment.

Although it would be very difficult to distinguish the eristic mode of managerial actions from heuristic ones in practice, it is possible to discuss possibilities of eristic managerial action from cues such as the following:

- Dogmatic and hostile attitudes toward concerns of unfairness.

- Poor association arguments that can easily fail a rationality test.

- Silence to avoid employee objections.
- An unwillingness to address objections or to seek persuasion.

- An abuse of dissociation arguments to deny attributions of unfairness to observations.

These clues do not wholly apply objective criteria. However, they serve as a valuable starting point for an argumentative analysis on interactional justice relationships within organizations. In this regard, an analysis can question how the failure of dialogs on unfairness can be tainted by the eristic attitudes of interlocutors. Solutions can be offered to alleviate such predicaments accordingly. In such pursuits, Perelman and Olbrechts-Tyteca's (1969) argumentation theory can be used as an analytical tool to investigate arguments. Finally, distinctions between eristic and heuristic modes of communication can be further elucidated through future studies.

\section{Implications for Justice Research}

While both Hayek's and Perelman's theories are not new at all, their application to organizational justice research brings about novel implications summarized as follows: (1) Exploring employees' naive procedural expectations without attending to managerial responses to unfairness claims is not conducive to impactful research that can improve fairness in organizations. (2) Interactional justice should be studied as a constituent of distributive justice.

Hayek's (1973) idea that organizational order is different from market order is essentially a factual-theoretical description, not a normative statement. Whereas, while the expounded views on interactional justice can be considered normative, they are rooted in the principles of free-market economy, and espouse conflict resolution by reasoning. Consequently, this paper draws on Hayek's (1973, 1976, 1979) theories along with Perelman's $(1963,1980)$ justice and Perelman and Olbrechts-Tyteca (1969)'s argumentation theory to inform researchers about employees' imperfect justice conceptions. It is suggested that employees ideally need to think according to the nature of organizations, and they should be aware of eristic attitudes of managers. Accordingly, this paper addresses how researchers should deal with employees' imperfect senses of justice. However, it does not aim to replace the descriptive method in justice research that focuses on perceptions. It just urges justice researchers to take the organizational and economic realities into their perspectives additionally.

As procedural justice is a mirage in organizations, researchers need to take this situation into consideration. Otherwise, the current trilogy might induce researchers to expose employees' unreflecting behavioral tendencies that are susceptible to be abused by managers. In this regard, the current trilogy might lead researchers to neglect hypocritical 
misuses of procedures by managers who can violate interactional justice, which is argued as a constituent of distributive justice in organizations. The situation is concerning as managerial impulses to employee justice perceptions are not sufficiently taken into consideration by research. Thus, further research can address this imbalance by attending to managers' attitudes to employee justice perceptions and by discovering how and why managers can resort to eristic argumentation. For instance, managers might be violating interactional justice to hide their irrational choices or vested interests. To explore these possibilities, case studies can be useful to produce various hypotheses about managerial reactions to injustice claims raised by their subordinates. Experimental or survey research can be designed to test those hypotheses.

When interactional justice is studied as a constituent of distributive justice, researchers might to an extent transcend relativist disputes on subjective moral views and be more conclusive about empirically recognizing injustice in organizations. With this perspective, antecedents and consequences of interactional injustice can be explored by further research alongside retaining the usual focus on employees' justice perceptions.

Funding This research received no specific grant from any funding agency in the public, commercial, or not-for-profit sectors.

\section{Compliance with Ethical Standards}

Conflict of interest The author declares that he has no conflict of interest.

Ethical Approval This article does not contain any studies with human participants performed by any of the authors.

Informed Consent For this type of study formal consent is not required.

\section{References}

Adams, J. S. (1963). Towards an understanding of inequity. The Journal of Abnormal and Social Psychology, 67(5), 422-436.

Ambrose, M. L., Seabright, M. A., \& Schminke, M. (2002). Sabotage in the workplace: The role of organizational injustice. Organizational Behavior and Human Decision Processes, 89(1), 947-965.

Arrow, K. J. (2012). Social choice and individual values (3rd ed.). New Haven, CT: Yale University Press.

Barney, J. B., \& Hesterly, W. (2006). Organizational economics: Understanding the relationship between organizations and economic analysis. In S. Clegg \& C. Hardy (Eds.), The Sage handbook of organization studies (pp. 111-148). London: SAGE Publications.

Batson, C. D., Kobrynowicz, D., Dinnerstein, J. L., Kampf, H. C., \& Wilson, A. D. (1997). In a very different voice: Unmasking moral hypocrisy. Journal of Personality and Social Psychology, 72(6), 1335-1348.

Battilana, J. (2006). Agency and institutions: The enabling role of individuals' social position. Organization, 13(5), 653-676.
Battilana, J., Leca, B., \& Boxenbaum, E. (2009). How actors change institutions: Towards a theory of institutional entrepreneurship. The Academy of Management Annals, 3(1), 65-107.

Bazerman, M. H., \& Sezer, O. (2016). Bounded awareness: Implications for ethical decision making. Organizational Behavior and Human Decision Processes, 136(9), 95-105.

Berry, A. (2017). Legitimization as a rhetorical process in a regulatory agency: An examination of rhetoric from the US Council for Higher Education Accreditation. Journal of Communication Management, 21(2), 124-139.

Bies, R. J. (2005). Are procedural justice and interactional justice conceptually distinct? In J. Greenberg \& J. A. Colquitt (Eds.) Handbook of organizational justice (pp. 85-112). Mahwah, NJ: Lawrence Erlbaum Associates.

Bies, R. J., \& Moag, J. F. (1986). Interactional justice: Communication criteria of fairness. Research on negotiations in organizations (pp. 43-55). Greenwich, CT: JAI Press.

Bitektine, A., \& Haack, P. (2015). The "macro" and the "micro" of legitimacy: toward a multilevel theory of the legitimacy process. Academy of Management Review, 40(1), 49-75.

Blader, S. L., \& Tyler, T. R. (2003). What constitutes fairness in work settings? A four-component model of procedural justice. Human Resource Management Review, 13(1), 107-126.

Blanpain, R., Bisom-Rapp, S., Corbett, W. R., Josephs, H. K., \& Zimmer, M. J. (2007). The global workplace: International and comparative employment law: Cases and materials. Cambridge: Cambridge University Press.

Bobocel, D. R., \& Gosse, L. (2015). Procedural justice in work organizations: A historical review and critical analysis. In R. Cropanzano \& M. L. Ambrose (Eds.), The Oxford handbook of justice in the workplace (pp. 51-88). Oxford: Oxford University Press.

Bobocel, D. R., \& Zdaniuk, A. (2005). How can explanations be used to foster organizational justice? In J. Greenberg \& J. A. Colquitt (Eds.), Handbook of organizational justice (pp. 469498). Mahwah, NJ: Lawrence Erlbaum Associates.

Boltanski, L., \& Thevenot, L. (2006). On justification: economies of worth. Princeton, NJ: Princeton University Press.

Booth, W. C. (2004). The rhetoric of rhetoric: The quest for effective communication. London: Blackwell Publishing.

Bowles, S., Kirman, A., \& Sethi, R. (2017). Retrospectives: Friedrich Hayek and the market algorithm. Journal of Economic Perspectives, 31(3), 215-230.

Boxenbaum, E., \& Battilana, J. (2005). Importation as innovation: Transposing managerial practices across fields. Strategic Organization, 3(4), 355-383.

Breslin, D., \& Wood, G. (2016). Rule breaking in social care: Hierarchy, contentiousness and informal rules. Work, Employment \& Society, 30(5), 750-765.

Brown, G., Bemmels, B., \& Barclay, L. J. (2010). The importance of policy in perceptions of organizational justice. Human Relations, 63(10), 1587-1609.

Brubaker, R. (2006). The limits of rationality an essay on the social and moral thought of Max Weber (2nd ed.). London: Routledge.

Brunsson, N. (2002). The organization of hypocrisy: Talk, decisions, and actions in organizations (2nd ed.). Oslo: Copenhagen Business School Press.

Brunsson, N. (2007). The consequences of decision-making. Oxford: OUP Oxford.

Camic, C., Gorski, P. S., \& Trubek, D. M. (2005). Max Weber's “Economy and society": A critical companion. Stanford, CA: Stanford University Press.

Cloutier, C., \& Langley, A. (2013). The logic of institutional logics: Insights from french pragmatist sociology. Journal of Management Inquiry, 22(4), 360-380. 
Cohen-Charash, Y., \& Spector, P. E. (2001). The role of justice in organizations: A meta-analysis. Organizational Behavior and Human Decision Processes, 86(2), 278-321.

Collins, B. J., \& Mossholder, K. W. (2017). Fairness means more to some than others: Interactional fairness, job embeddedness, and discretionary work behaviors. Journal of Management, 43(2), 293-318.

Colquitt, J. A. (2001). On the dimensionality of organizational justice: A construct validation of a measure. Journal of Applied Psychology, 86(3), 386-400.

Colquitt, J. A., Conlon, D. E., Wesson, M. J., Porter, C. O. L. H., \& Ng, K. Y. (2001). Justice at the millennium: A meta-analytic review of 25 years of organizational justice research. Journal of Applied Psychology, 86(3), 425-445.

Colquitt, J. A., Scott, B. A., Rodell, J. B., Long, D. M., Zapata, C. P., Conlon, D. E., et al. (2013). Justice at the millennium, a decade later: A meta-analytic test of social exchange and affect-based perspectives. Journal of Applied Psychology, 98, 199-236.

Colquitt, J. A., \& Zipay, K. P. (2015). Justice, fairness, and employee reactions. Annual Review of Organizational Psychology and Organizational Behavior, 2(1), 75-99.

Conlon, D. E., Meyer, C. J., \& Nowakowski, J. M. (2005). How does organizational justice affect performance, withdrawal, and counterproductive behavior? In J. Greenberg \& J. A. Colquitt (Eds.), Handbook of organizational justice (pp. 301-328). Mahwah, NJ: Lawrence Erlbaum Associates.

Crawshaw, J. R., Cropanzano, R., Bell, C. M., \& Nadisic, T. (2013). Organizational justice: New insights from behavioural ethics. Human Relations, 66(7), 885-904.

Crawshaw, J. R., Van Dick, R., \& Brodbeck, F. C. (2012). Opportunity, fair process and relationship value: Career development as a driver of proactive work behaviour. Human Resource Management Journal, 22(1), 4-20.

Cropanzano, R., Bowen, D., \& Gilliland, S. (2007). The management of organizational justice. Academy of Management Perspectives, 21(4), 34-49.

Cropanzano, R., Goldman, B., \& Folger, R. (2003). Deontic justice: The role of moral principles in workplace fairness. Journal of Organizational Behavior, 24(8), 1019-1024.

Cropanzano, R., Massaro, S., \& Becker, W. J. (2017). Deontic justice and organizational neuroscience. Journal of Business Ethics, 144(4), 733-754.

Cropanzano, R., Prehar, C. A., \& Chen, P. Y. (2002). Using social exchange theory to distinguish procedural from interactional justice. Group \& Organization Management, 27(3), 324-351.

Cugueró-Escofet, N., \& Fortin, M. (2014). One justice or two?: A model of reconciliation of normative justice theories and empirical research on organizational justice. Journal of Business Ethics, 124(3), 435-451.

Cuguero-Escofet, N., Fortin, M., \& Canela, M.-A. (2014). Righting the wrong for third parties: How monetary compensation, procedure changes and apologies can restore justice for observers of injustice. Journal of Business Ethics, 122(2), 253-268.

Cullen, L. K., Gerbasi, A., \& Chrobot-Mason, D. (2018). Thriving in central network positions: The role of political skill. Journal of Management, 44(2), 682-706.

Currie, D., Gormley, T., Roche, B., \& Teague, P. (2017). The management of workplace conflict: Contrasting pathways in the HRM literature. International Journal of Management Reviews, 19(4), 492-509.

Dailey, R. C., \& Kirk, D. J. (1992). Distributive and procedural justice as antecedents of job dissatisfaction and intent to turnover. Human Relations, 45(3), 305-317.

Daumann, F. (2007). Evolution and the rule of law: Hayek's concept of liberal order reconsidered. Journal of Libertarian Studies, 21(4), 123-150.
Davidson, J. (2004). Hypocrisy and the politics of politeness: Manners and morals from Locke to Austen. Cambridge, UK: Cambridge University Press.

den Nieuwenboer, N. A., da Cunha, J. V., \& Treviño, L. K. (2017). Middle managers and corruptive routine translation: The social production of deceptive performance. Organization Science, 28(5), 781-803.

Erkama, N., \& Vaara, E. (2010). Struggles over legitimacy in global organizational restructuring: A rhetorical perspective on legitimation strategies and dynamics in a shutdown case. Organization Studies, 31(7), 813-839.

Ferris, G. R., Treadway, D. C., Perrewe, P. L., Brouer, R. L., Douglas, C., \& Lux, S. (2007). Political skill in organizations. Journal of Management, 33(3), 290-320.

Folger, R., \& Greenberg, J. (1985). Procedural justice: An interpretive analysis of personnel systems. Research in Personnel and Human Resources Management, 3(1), 141-183.

Fortin, M. (2008). Perspectives on organizational justice: Concept clarification, social context integration, time and links with morality. International Journal of Management Reviews, 10(2), 93-126.

Fortin, M., Cojuharenco, I., Patient, D., \& German, H. (2016). It is time for justice: How time changes what we know about justice judgments and justice effects. Journal of Organizational Behavior, 37(S1), 30-56.

Fortin, M., \& Fellenz, M. R. (2008). Hypocrises of fairness: Towards a more reflexive ethical base in organizational justice research and practice. Journal of Business Ethics, 78(3), 415-433.

Foss, S. K., Foss, K. A., \& Trapp, R. (2014). Contemporary perspectives on rhetoric. Long Grove, IL: Waveland Press.

Friedland, R., \& Alford, R. R. (1991). Bringing society back in: Symbols, practices, and institutional contradictions. In W. W. Powell \& P. J. Dimaggio (Eds.), The new institutionalism in organizational analysis (pp. 232-263). Chicago, IL: University of Chicago Press.

Garud, R., Hardy, C., \& Maguire, S. (2007). Institutional entrepreneurship as embedded agency: An introduction to the special issue. Organization Studies, 28(7), 957-969.

Goldman, B., \& Cropanzano, R. (2015). Justice and fairness are not the same thing. Journal of Organizational Behavior, 36(2), 313-318.

Gotsis, G. N., \& Kortezi, Z. (2010). Ethical considerations in organizational politics: Expanding the perspective. Journal of Business Ethics, 93(4), 497-517.

Green, S. E. (2004). A rhetorical theory of diffusion. The Academy of Management Review, 29(4), 653-669.

Green, S. E., Babb, M., \& Alpaslan, C. M. (2008). Institutional field dynamics and the competition between institutional logics. Management Communication Quarterly, 22(1), 40-73.

Green, S. E., \& Li, Y. (2011). Rhetorical institutionalism: Language, agency, and structure in institutional theory since Alvesson 1993. Journal of Management Studies, 48(7), 1662-1697.

Greenberg, J. (1988). Cultivating an image of justice: Looking fair on the job. Academy of Management Executive, 2(2), 155-158.

Greenberg, J. (2009). Everybody talks about organizational justice, but nobody does anything about it. Industrial and Organizational Psychology, 2(02), 181-195.

Harmon, D. J., Green, S. E., \& Goodnight, G. T. (2015). A model of rhetorical legitimation: The structure of communication and cognition underlying institutional maintenance and change. Academy of Management Review, 40(1), 76-95.

Hayek, F. A. (1960). The constitution of liberty. London: The University of Chicago Press.

Hayek, F. A. (1973). Law, legislation and liberty, Vol. 1, rules and order. Chicago, IL: University of Chicago Press.

Hayek, F. A. (1976). Law, legislation and liberty, Vol. 2: The mirage of social justice. London: University of Chicago Press. 
Hayek, F. A. (1979). Law, legislation and liberty, Vol. 3 the political order of free people. Chicago, IL: The University of Chicago Press.

He, H., Zhu, W., \& Zheng, X. (2014). Procedural justice and employee engagement: Roles of organizational identification and moral identity centrality. Journal of Business Ethics, 122(4), 681-695.

Higgins, C. A., Judge, T. A., \& Ferris, G. R. (2003). Influence tactics and work outcomes: A meta-analysis. Journal of Organizational Behavior, 24(1), 89-106.

Higgins, C., Stubbs, W., \& Milne, M. (2018). Is sustainability reporting becoming institutionalised? The role of an issues-based field. Journal of Business Ethics, 147(2), 309-326.

Hodson, R., Roscigno, V. J., Martin, A., \& Lopez, S. H. (2013). The ascension of Kafkaesque bureaucracy in private sector organizations. Human Relations, 66(9), 1249-1273.

Hoefer, R. L., \& Green, S. E. (2016). A rhetorical model of institutional decision making: The role of rhetoric in the formation and change of legitimacy judgments. Academy of Management Review, 41(1), 130-150.

Jackall, R. (2010). Moral mazes: The world of corporate managers. Oxford: Oxford University Press.

Johnson, C., Dowd, T. J., \& Ridgeway, C. L. (2006). Legitimacy as a social process. Annual Review of Sociology, 32, 53-78.

Kapoutsis, I., Papalexandris, A., Thanos, I. C., \& Nikolopoulos, A. G. (2012). The role of political tactics on the organizational context-career success relationship. The International Journal of Human Resource Management, 23(9), 1908-1929.

Kersley, B., Alpin, C., Forth, J., Bryson, A., Bewley, H., Dix, G., et al. (2006). Inside the workplace: Findings from the 2004 workplace employment relations survey. London: Routledge.

Kickul, J. (2001). When organizations break their promises: Employee reactions to unfair processes and treatment. Journal of Business Ethics, 29(4), 289-307.

Kish-Gephart, J. J., Harrison, D. A., \& Treviño, L. K. (2010). Bad apples, bad cases, and bad barrels: Meta-analytic evidence about sources of unethical decisions at work. Journal of Applied Psychology, 95(1), 1-31.

Kurdoglu, R. S. (2019). An inquiry into pseudo-legitimations: A framework to investigate the clash of managerial legitimations and employees' unfairness claims. Business Ethics: A European Review, 28(1), 129-138. https://doi.org/10.1111/beer.12202.

Lawrence, T. B., Leca, B., \& Zilber, T. B. (2013). Institutional work: Current research, new directions and overlooked issues. Organization Studies, 34(8), 1023-1033.

Lawrence, T., Suddaby, R., \& Leca, B. (2011). Institutional work: Refocusing institutional studies of organization. Journal of Management Inquiry, 20(1), 52-58.

Lefkowitz, J. (2009). Promoting employee justice: It's even worse than that. Industrial and Organizational Psychology, 2(2), 221-225.

Leventhal, G. S. (1976). The distribution of rewards and resources in groups and organizations. In L. Berkowitz \& W. Walster (Eds.), Advances in experimental social psychology (pp. 91-131). New York: New York Academic Press.

Leventhal, G. S. (1980). What should be done with equity theory? New approaches to the study of fairness in social relationships. In K. Gergen, M. Greenberg, \& R. Willis (Eds.), Social exchange (pp. 27-55). New York, NY: Plenum Press.

Lind, E. A. (2001). Fairness heuristic theory: Justice judgments as pivotal cognitions in organizational relations. In J. Greenberg \& R. Cropanzano (Eds.), Advances in organizational justice (pp. 56-88). Stanford, CA: Stanford University Press.

Lister, A. (2013). The "mirage" of social Justice: Hayek against (and for) Rawls. Critical Review, 25(3-4), 409-444.

Loi, R., Lam, L. W., \& Chan, K. (2012). Coping with job insecurity: The role of procedural justice, ethical leadership and power distance orientation. Journal of Business Ethics, 108(3), 361-372.
Maccoun, R. J. (2005). Voice, control, and belonging: The doubleedged sword of procedural fairness. Annual Review of Law and Social Science, 1, 171-201.

Macedo, S. (1999). Hayek's liberal legacy. Cato Journal, 19(2), 289.

Margolis, J. (1995). Philosophy in the "new" rhetoric, rhetoric in the "new" philosophy. In S. Mailloux (Ed.), Rhetoric, sophistry, pragmatism (pp. 109-138). Cambridge: Cambridge University Press.

Matta, F. K., Scott, B. A., Colquitt, J. A., Koopman, J., \& Passantino, L. G. (2017). Is consistently unfair better than sporadically fair? An investigation of justice variability and stress. Academy of Management Journal, 60(2), 743-770.

Mccabe, D. M., \& Rabil, J. M. (2002). Administering the employment relationship: The ethics of conflict resolution in relation to justice in the workplace. Journal of Business Ethics, 36(1), 33-48.

Melkonian, T., Monin, P., \& Noorderhaven, N. G. (2011). Distributive justice, procedural justice, exemplarity, and employees' willingness to cooperate in M\&A integration processes. Human Resource Management, 50(6), 809-837.

Meyer, J. W., \& Rowan, B. (1977). Institutionalized organizations: Formal structure as myth and ceremony. American Journal of Sociology, 83(2), 340-363.

Micelotta, E., Lounsbury, M., \& Greenwood, R. (2017). Pathways of institutional change: An integrative review and research agenda. Journal of Management, 43(6), 1885-1910.

Misangyi, V. F., \& Weaver, G. R. (2008). Ending corruption: The interplay among institutional logics, resources, and institutional entrepreneurs. Academy of Management Review, 33(3), 750-770.

Percival, R. S. (2012). The myth of the closed mind: Explaining why and how people are rational. Chicago, IL: Open Court Publishing.

Perelman, C. (1963). The idea of justice and the problem of argument. London: Routledge \& Kegan Paul.

Perelman, C. (1979). The new rhetoric and the humanities: Essays on rhetoric and its applications. Dordrecht: D. Reidel Publishing Company.

Perelman, C. (1980). Justice, law, and argument: Essays on moral and legal reasoning. London: D. Reidel Publishing Company.

Perelman, C. (1982). The realm of rhetoric. London: University of Notre Dame Press.

Perelman, C., \& Olbrechts-Tyteca, L. (1969). The new rhetoric: A treatise on argumentation (E-book ver.). London: University of Notre Dame Press.

Polman, E., \& Ruttan, R. L. (2012). Effects of anger, guilt, and envy on moral hypocrisy. Personality and Social Psychology Bulletin, 38(1), 129-139.

Poulakos, J. (1995). Sophistical rhetoric in classical Greece. Columbia, SC: University of South Carolina Press.

Reay, T., Golden-Biddle, K., \& Germann, K. (2006). Legitimizing a new role: Small wins and microprocesses of change. The Academy of Management Journal, 49(5), 977-998.

Rosen, C. C., Kacmar, K. M., Harris, K. J., Gavin, M. B., \& Hochwarter, W. A. (2017). Workplace politics and performance appraisal: A two-study, multilevel field investigation. Journal of Leadership and Organizational Studies, 24(1), 20-38.

Rupp, D. E., Shapiro, D. L., Folger, R., Skarlicki, D. P., \& Shao, R. (2017). A critical analysis of the conceptualization and measurement of organizational Justice: Is it time for reassessment? Academy of Management Annals, 11(2), 919-959.

Schwartz, M. S. (2016). Ethical decision-making theory: An integrated approach. Journal of Business Ethics, 139(4), 755-776.

Scott, W. R. (2001). Institutions and organizations (2nd ed.). Thousand Oaks, CA: Sage.

Seo, M.-G., \& Creed, W. E. D. (2002). Institutional contradictions, praxis, and institutional change: A dialectical perspective. Academy of Management Review, 27(2), 222-247. 
Shapiro, D. L., Buttner, E. H., \& Barry, B. (1994). Explanations: What factors enhance their perceived adequacy. Organizational Behavior and Human Decision Processes, 58(3), 346-368.

Shaw, J. C., Wild, E., \& Colquitt, J. A. (2003). To justify or excuse?: A meta-analytic review of the effects of explanations. Journal of Applied Psychology, 88(3), 444-458.

Sidanius, J., \& Pratto, F. (2011). Social dominance theory. In P. A. M. Van Lange, A. W. Kruglanski, \& E. Tory Higgins (Eds.), Handbook of theories of social psychology (Vol. 2, pp. 418-438). London: SAGE Publications Ltd.

Sidanius, J., Pratto, F., Laar, C. Van, \& Levin, S. (2004). Social dominance theory: Its agenda and method. Political Psychology, 25(6), 845-880.

Skitka, L. J. (2002). Do the means always justify the ends, or do the ends sometimes justify the means? A value protection model of justice reasoning. Personality and Social Psychology Bulletin, $28(5), 588-597$.

Skitka, L. J., \& Houston, D. A. (2001). When due process is of no consequence: Moral mandates and presumed defendant guilt or innocence. Social Justice Research, 14(3), 305-326.

Skitka, L. J., \& Mullen, E. (2002). Understanding judgments of fairness in a real-world political context: A test of the value protection model of justice reasoning. Personality and Social Psychology Bulletin, 28(10), 1419-1429.

Stone, J., \& Fernandez, N. C. (2008). To practice what we preach: The use of hypocrisy and cognitive dissonance to motivate behavior change. Social and Personality Psychology Compass, 2(2), $1024-1051$.

Suchman, M. C. (1995). Managing legitimacy: Strategic and institutional approaches. The Academy of Management Review, 20(3), 571-610.

Suddaby, R., Bitektine, A., \& Haack, P. (2017). Legitimacy. Academy of Management Annals, 11(2), 451-478.

Suddaby, R., \& Greenwood, R. (2005). Rhetorical strategies of legitimacy. Administrative Science Quarterly, 50(1), 35-67.

Sung, S. Y., Choi, J. N., \& Kang, S. C. (2017). Incentive pay and firm performance: moderating roles of procedural justice climate and environmental turbulence. Human Resource Management, 56(2), 287-305.

Thibaut, J., \& Walker, L. (1975). Procedural justice: A psychological analysis. Hillsdale, NJ: L. Erlbaum Associates.

Thibaut, J., \& Walker, L. (1978). A theory of procedure. California Law Review, 66(3), 541-566.

Thornton, P. H., \& Ocasio, W. (1999). Institutional logics and the historical contingency of power in organizations: Executive succession in the higher education publishing industry, 1958-1990. American Journal of Sociology, 105(3), 801-843.

Thornton, P. H., \& Ocasio, W. (2013). Institutional logics. In R. Greenwood, C. Oliver, K. Sahlin, \& R. Suddaby (Eds.), The Sage handbook of organizational institutionalism (pp. 99-129). London: SAGE Publications Ltd.

Thornton, P. H., Ocasio, W., \& Lounsbury, M. (2012). The institutional logics perspective: A new approach to culture, structure, and process. Oxford: Oxford University Press.

Tindale, C. W. (2015). The philosophy of argument and audience reception. Cambridge: Cambridge University Press.

Törnblom, K., \& Kazemi, A. (2015). Distributive justice: Revisiting past statements and reflecting on future prospects. In R. S. Cropanzano \& M. L. Ambrose (Eds.), The Oxford handbook of justice in the workplace (pp. 15-50). New York, NY: Oxford University Press.
Tost, L. P. (2011). An integrative model of legitimacy judgments. Academy of Management Review, 36(4), 686-710.

Tyler, T. R. (2006). Psychological perspectives on legitimacy and legitimation. Annual Review of Psychology, 57(1), 375-400.

Tyler, T. R., \& Lind, E. A. (1992). A relational model of authority in groups. In M. Zanna (Ed.), Advances in experimental social psychology (pp. 115-192). New York, NY: Academic Press.

Van Dijke, M., De Cremer, D., Brebels, L., \& Quaquebeke, N. Van. (2015). Willing and able: Action-state orientation and the relation between procedural justice and employee cooperation. Journal of Management, 41(7), 1982-2003.

Vanberg, V. J. (2014). Darwinian paradigm, cultural evolution and human purposes: On F.A. Hayek's evolutionary view of the market. Journal of Evolutionary Economics, 24(1), 35-57.

Vermunt, R., \& Steensma, H. (2001). Stress and justice in organizations: An exploration into justice processes with the aim to find mechanisms to reduce stress. In R. Cropanzano (Ed.), Justice in the workplace: From theory to practice (Vol. 2, pp. 27-48). London: Lawrence Erlbaum.

Vigoda, E. (2000). Organizational politics, job attitudes, and work outcomes: Exploration and implications for the public sector. Journal of Vocational Behavior, 57(3), 326-347.

Wagner-Tsukamoto, S. (2005). An economic approach to business ethics: Moral agency of the firm and the enabling and constraining effects of economic institutions and interactions in a market economy. Journal of Business Ethics, 60(1), 75-89.

Wagner-Tsukamoto, S. (2008). Contrasting the behavioural business ethics approach and the institutional economic approach to business ethics: Insights from the study of quaker employers. Journal of Business Ethics, 82(4), 835-850.

Walker, B., \& Hamilton, R. T. (2011). Employee-employer grievances: A review. International Journal of Management Reviews, 13(1), $40-58$.

Walton, D. N. (1992). Plausible argument in everyday conversation. Albany, NY: State University of New York Press.

Walton, D. N. (1999). One-sided arguments: A dialectical analysis of bias. Albany, NY: State University of New York Press.

Wang, Y.-D., \& Hsieh, H.-H. (2013). Organizational ethical climate, perceived organizational support, and employee silence: A crosslevel investigation. Human Relations, 66(6), 783-802.

Weber, M. (1991). From Max Weber: Essays in sociology (New ed.). London: Routledge.

Weber, J., \& Wasieleski, D. (2001). Investigating influences on managers' moral reasoning: The impact of context and personal and organizational factors. Business \& Society, 40(1), 79-110.

Xu, A., Loi, R., \& Ngo, H. Y. (2017). Ethical leadership behavior and employee justice perceptions: The mediating role of trust in organization. Journal of Business Ethics, 134(3), 493-504.

Zehnder, C., Herz, H., \& Bonardi, J. P. (2017). A productive clash of cultures: Injecting economics into leadership research. Leadership Quarterly, 28(1), 65-85.

Zollo, L., Pellegrini, M. M., \& Ciappei, C. (2017). What sparks ethical decision making? The interplay between moral intuition and moral reasoning: lessons from the scholastic doctrine. Journal of Business Ethics, 145(4), 681-700.

Publisher's Note Springer Nature remains neutral with regard to jurisdictional claims in published maps and institutional affiliations. 